\title{
FELMÉRÉS AZ ÁFACSÖKKENTÉS HALHÚS FOGYASZTÁSRA GYAKOROLT HATÁSÁRÓL EGY SZEGEDI KÖZÉPISKOLA TANULÓI KÖRÉBEN
}

\author{
Zsótér Brigitta - Ács Eszter
}

\begin{abstract}
Absztrakt: Célul tüztük ki, hogy feltérképezzük a halfogyasztási szokásokat Szegeden egy gimnáziumban. 2017-ben már végeztünk egy felmérést ebben a témában. Kutatásunk előtt feltételeztük, hogy többen lesznek, akik nem fogyasztanak halat, mint a halfogyasztók. Válaszadóink ezt megcáfolták. 2018. januárjában a fogyasztási célú halakra vonatkozó áfakulcs 5\%-ra redukálódott, ez okot adott a kutatás folytatására, mely során új felmérést végeztünk, más hipotéziseket is vizsgáltunk, így született meg cikkünk. Hazánk egy före jutó halfogyasztási statisztikája elkeserítő. Ennek egyik oka lehetett a hal ára, amelyre megoldás lehet az áfacsökkentés. Egyre többet tudunk az egészséges táplálkozásról, mégsem teszünk érte eleget. A hal számos szervezetre gyakorolt jótékony hatással rendelkezik. Cikkünkben ezeket is ismertetjük. A célcsoport fiatalnak bizonyulhat, azonban úgy véljük az egészséges táplálkozásra való törekvést fiatalon szükséges elkezdeni.
\end{abstract}

\begin{abstract}
We have set the goal of mapping fish consumption habits in Szeged in a secondary grammar school. We already conducted a survey on this topic in 2017. Before our research we assumed that there would be more who do not consume fish than those who do. Our responders refuted this. In January 2018 VAT on fish for human consumption was reduced to 5\% which provided reason to continue the research. During this, we have conducted a new survey, observed other hypotheses, so our thesis was born. The per capita fish consumption statistics of Hungary is depressing. One of the reasons to this could be the price of fish, for which VAT reduction could be a resolution. We know more and more about healthy nutrition, yet we do not do enough for this. Fish has got several beneficiary effects on our organism. In our thesis we describe them, too. Our target group may be young, but we suppose endeavour for healthy nutrition should be started when young.
\end{abstract}

Kulcsszavak: hal, fogyasztás, Z-próba, ÁFA

Keywords: fish, consumption, Z-test, VAT

\section{Bevezetés}

Témánk a halhús fogyasztási szokások feltérképezése egy Szegeden található középiskola tanulóinak körében. Továbbá vizsgálni kívántuk, hogy milyen hatással van a halfogyasztásra az áfacsökkentés. Rendkívül fontosnak tartjuk az egészséges életmódra való törekvést. Ezen életvitelnek szerves részét képezi a rendszeres halfogyasztás (Kiss et al., 2016). Témaválasztásunkat legfőképpen az aktualitás indokolja, hiszen az áfacsökkentés 2018. január 1-én lépett életbe a fogyasztási célú halak vonatkozásában. Meggyőződésünk, hogy a megfelelö életmódot fiatalkorban, szinte még gyermekként szükséges elsajátítani annak érdekében, hogy felnőttként ez az életvitel már természetes legyen. Így jutottunk arra a következtetésre, hogy a középiskolás korosztályt szeretnénk górcső alá venni, hiszen az ebben a korban élők már képesek önálló döntést hozni, azonban még nem rendelkeznek végleges, rögzült szokásokkal életmódjukat illetően (Kontor et al., 2016).

Kérdőívet készítettünk, amit a Szegedi Radnóti Miklós Kísérleti Gimnázium diákjai töltöttek ki. Primer kutatás segítségével az alábbi hipotéziseket kívántuk vizsgálni: 
1. Feltételezzük, hogy a kérdöivet kitöltö halfogyasztók nagyobb része csupán ritkán (maximum évi 1-2 alkalommal) fogyaszt halat.

2. A megkérdezettek legalább 50\%-a szerint jót tesz az egészségnek a rendszeres halfogyasztás.

3. A beltartalmi értékek közül a legismertebb az omega-3 zsírsav.

4. A válaszadók többsége szerint (>50\%) növelni kellene a halhúsfogyasztást.

5. A kitöltők (családjában) növekedett a halfogyasztás mértéke az áfacsökkentés hatására.

Továbbá kíváncsiak voltunk, hogy milyen hatással van az áfacsökkentés a halhús fogyasztói árára. Ennek érdekében felkerestük a Szegedfish Kft-t, hogy polcfelmérést végezhessünk. Egy bizonyos árucikk vonatkozásában korábbi évek adataival is segítették a munkánkat, így figyelemmel kísérhettük egy termék árának alakulását az áfacsökkentés előtt és azt követően is.

Az emberiség táplálékforrásaként az ősidők óta megjelenik a víz, és a benne található élőlények. Öseink táplálkozási szokásairól meglehetősen kevés írásos emlék maradt fenn. Azonban tény, hogy a vándorlás során az ember letelepedése alkalmával minden esetben vízhez közeli területet választott az életben maradás érdekében (Herman, 1887). Számos hallal készült ételt és több tartósítási módszert is ismertek. A tartósítást a korábbi századokban sózással vagy szárítással oldották meg (Pintér, 1989). Egyre többen kezdtek halászattal foglalkozni, de az 1800-as évek idején elinduló folyamszabályozás rendkívüli korlátok közé helyezte az ártéri halászatot (Takács, 2006). Meglepő módon a halászlé múltja sem nyúlik régebbi időkre, az első feljegyzések 1828-ból származnak ezen étel tekintetében (TasnádiSzilágyi, 2001). A közelmúltban népszerüsödött számos táplálkozási csoport, mint például a vegán, vagy a vércsoport alapján meghatározott diéta is. Ennek hatására módosultak az étkezési attitüdök is határainkon belül és azokon túl is. Az 1900-as évek dereka tájától a vásárlói magatartás az egészséges táplálkozás irányába mozdult Magyarországon. A fogyasztók belátták, hogy az egészséges táplálkozással számos komoly betegség megelőzhető. Az egészségtelen étkezés a megbetegedések közel 25\%-át elősegíti (Antal-Rodler, 2005).

A halfogyasztásnak társadalmi és kulturális aspektusai is voltak. Ez azonban az idő múlásával változik, amelyben minden kétséget kizáróan a globalizációnak is jelentős szerepe van, hiszen ennek hatására alakult ki az úgynevezett „orientációs krízis" a termékek és az élelmiszerek vonatkozásában egyaránt (Túry, 2008).

A tradicionális étkezési szokások mára már felbomlottak, úgynevezett foodtrendek alakultak ki. Hazánkban is megfigyelhető e trendek térhódítása. Mára egy ilyen trendként rögzült az egészséges életmód is (Töröcsik, 2007). Ennek kapcsán létrejött az úgynevezett egészségparadoxon. Ez azt állítja, hogy annak ellenére, hogy egyre több tudomást szerzünk a megfelelő táplálkozásról, ezt a gyakorlati életünkben nem igazán alkalmazzuk (Lantos, 2010). Az egészségparadoxon arra enged következtetni, hogy a fogyasztók gondolkodása a témát illetően meglehetősen szelektív (Fürediné, 2008). A szervezet megfelelö müködését szolgáló élelmiszerek pozitív hatásait csak akkor figyelhetjük meg, ha más élelmiszerek tekintetében is tudatosan vásárolunk (Rácz, 2013). 
A haltenyésztés mára ipari méreteket öltött (Pintér, 1989). A legkedveltebb hazai halfajtának a ponty mondható. Ez a tradícióra és a rögzült táplálkozási szokásokra vezethető vissza, így számos háztartásban csak karácsony idején, az ünnepi étkezésnél kerül elő a hal (Takács, 2006).

Magyarországon az egyik legalacsonyabb az egy före jutó halfogyasztás mértéke évenként. Ennek hatására az elmúlt időszakban középpontba került a halfogyasztás népszerüsítése. Egy felnőtt ember ízvilága és táplálkozási szokásai nem formálhatóak annyira, mint egy gyermeké. A prevencióban szintén jelentős szereppel rendelkezik az egészséges táplálkozás, így még inkább szükséges a halfogyasztás mértékének növelése (MDOSZ, 2007).

A KSH adatai alapján 2016-ban az egy före jutó húsfogyasztás mértéke hazánkban $66,4 \mathrm{~kg}$ volt. A halfogyasztás ugyanezen táblázat alapján 5,7 -es értékkel bír, ami csökkenést mutat a 2015-ös évhez képest (KSH, 2016). Szembetünő eltérés figyelhető meg világszerte az egy före jutó éves halfogyasztás tekintetében. Az európai lakosság egy före jutó halfogyasztása átlagosan $28 \mathrm{~kg}$-ra tehető éves szinten (Szakály, 2017).

Jelentős akadálynak bizonyult a halhús kereskedelmi ára. Ezt népszerüsége miatt az élő ponttyal szemléltetnénk. Az elmúlt években $1400 \mathrm{Ft}$ körül alakult a kilogrammonkénti ár, ami viszonylag soknak mondható, tekintve, hogy feltisztítva mennyit veszít a tömegéből. Ráadásul még így is vigyázni kell a szálkákkal. Az áfacsökkentés hatása a fogyasztói árra vitatott. Megoszlanak a vélemények abban a tekintetben, hogy a kereskedőnek vagy a fogyasztónak lett kedvezőbb a helyzete (HVG, 2018).

2018. január 1-től 27\%-ról 5\%-ra módosult a fogyasztási célú halakra vonatkozó általános forgalmi adó. Ezt az intézkedést a hazai halfogyasztás mértékének növelése céljából indítványozták, abban bízva, hogy így olcsóbban juthatnak az emberek halhúshoz és ez által megnövelhetik a keresletet e termék vonatkozásában (HVG, 2018).

Napjainkban az élő hal ára valóban alacsonyabb, ma egy kilogramm tömegü élő pontyot 1000 Forintért vásárolhatunk meg. A nagy népszerüségnek örvendő ponty szelet ára a tavalyi év során 2400 Ft körül alakult kilogrammonként, ez mára 2000 $\mathrm{Ft} / \mathrm{kg}$ kereskedelmi árra mérséklődött (HVG, 2018). Az említett összegek természetesen eltérhetnek annak függvényében, hogy az ember hol vásárol.

Polcfelmérés céljából megkerestük a Szegedfish Kft-t. Rendkívül széles kínálatot biztosítanak. Munkánk során csupán egy termék árát vizsgáltuk különböző gazdasági évek tekintetében. 2016-ban az élő ponty kereskedelmi ára az említett vállalatnál $950 \mathrm{Ft}$ volt kilogrammonként. 2017-re ez $1090 \mathrm{Ft} / \mathrm{kg}$-ra emelkedett. Az áfacsökkentés tárgyévében, azaz 2018-ban ez az ár 999 Ft/kg (Szegedfish, 2018). Az áfacsökkentés hatására ugyan mérséklődött az ár az előző évhez képest, azonban 2016-ban olcsóbban hozzá lehetett jutni az élő pontyhoz.

A várt 20-22\%-os árcsökkenés elmaradt. Ennek számos oka lehet. A MA-HAL, a haltermelök szakmai szervezetének véleménye alapján az idei évben ismét fellángolt az úgynevezett halherpesz. Ez a betegség az emberre nem veszélyes, 
azonban ez az oka annak, hogy idén ötödével kevesebb a halmennyiség (HVG, 2018).

Elmondható, hogy a rendszeres halfogyasztás szerves részét képezheti a kiegyensúlyozott életmódnak és egészséges táplálkozásnak (Szakály, 2017). A halhús teljes értékü fehérjét tartalmaz, így kiválóan alkalmas más húsok helyettesítésére is. Vízben oldódó vitaminokat (B1, B2, B6, B12, C) és zsírban oldódó társaikat $(\mathrm{A}, \mathrm{D}, \mathrm{E}, \mathrm{K}$,), ásványi anyagokat $(\mathrm{Ca}, \mathrm{Mg}, \mathrm{P}, \mathrm{Fe}, \mathrm{Cu})$ egyaránt tartalmaznak a többszörösen telítetlen zsírsavak mellett, így az egészséges táplálkozásban betöltött szerepük kiemelkedő. A legtöbb ajánlás szerint heti rendszerességgel kellene halat fogyasztanunk (Rodler, 2005).

Az édesvízi busa omega-3 zsírsav tartalma jelentős, annak ellenére, hogy az édesvízben fellelhető halak ezzel a többszörösen telítetlen zsírsavval nem vagy csak nagyon kis mértékben rendelkeznek. Ezen zsírsavak a szervezet számára nélkülözhetetlenek. Jelentős szerepet játszanak a vérrögök kialakulásának mérséklésében és az aritmiás szívmüködés megelőzésében (Rodler, 2005). Ebbe a csoportba tartozik az omega-3 zsírsav is. Ez szervezetünk számára nélkülözhetetlen, azonban önmagának nem képes előállítani, tehát nagy hangsúlyt kell fektetni a pótlására, melyet megfelelő élelmiszerek fogyasztásával érhetünk el. Gátolják a vérrögképződést, ezzel csökkentik a szív- és érrendszeri megbetegedések kialakulásának valószínűségét (MDOSZ, 2007).

\section{Anyag és módszer}

Kérdőívünk összeállítása során felhasználtuk a korábbi kutatás idején használt kérdéseket, „itemeket” is, melyeket módosítottunk, aktualizáltunk. A válaszadás anonim volt (Szakály, 2009).

Több szakaszból áll az adatfelvétel. Első lépés az adatfelvétel előzetes megtervezése, majd a célcsoport, azaz a kérdöív kitöltői körének meghatározása, $\mathrm{s}$ csupán ezt követően végezhető el a kitöltetés (Horváth, 2004).

A kérdések megfogalmazásának alkalmával törekedni kell rá, hogy a feltett kérdések egyértelmüek, egyszerúek és könnyen érthetőek legyenek (Majoros, 1997).

A kutatás módszertana:

A piackutató szakemberek az információgyüjtést három fő típusba sorolják:

1. Megfigyelés

2. Primer (elsődleges)

3. Szekunder (másodlagos) adatgyüjtés.

Primer az adat, ha az újszerü és azt más még nem közölte, szekunder pedig, ha azt már valaki más céllal összegyüjtötte és azt közzétette (Kotler, 1999). Kutatási munkánk két fö részre bontható. Az első részben bemutatjuk a halfogyasztás szakirodalmi hátterét különböző aspektusokat figyelembe véve, egészen napjainkig, az aktualitásokig. Ez a rész képezi a szekunder kutatási részt. Az ezt követő részben pedig saját kutatásunk végeredményét és számításokhoz szükséges információkat kívánjuk bemutatni. Ez a kutatás primer része.

Közvélemény-kutatás során jellemzően hasonló, visszatérő kérdéseket tesznek fel, továbbá aránylag nagy minta elemszámmal végzik a vizsgálatokat. Ennek az oka, 
hogy a módszer nem az egyén véleményére irányul, hanem a sokaságra, a tömegre, így ezen eljárás során további fontos szempont a begyüjtött adatok feldolgozhatósága statisztikai szempontból, valamint maga a feldolgozás is (Majoros, 1997).

A kérdőív megszerkesztését követően próbakitöltetést végeztünk. Ez lehetőséget biztosított arra, hogy kiderüljön, hogy a kérdéssor logikai felépítése megfelelö, a kérdésformák ideálisak-e, kérdéseim mindenki számára egyértelmünek bizonyulnak-e vagy korrekció szükséges (Lehota, 2001).

Kérdöívünket elektronikusan juttattuk el a Szegedi Radnóti Miklós Kísérleti Gimnáziumba. A kitöltés 2018. szeptember 1. és október 5. között zajlott. Összesen 411 kitöltött kérdőívet kaptunk, azonban ebből 4 nem minősült értékelhetőnek, így vizsgálatainkhoz 407-es minta elemszámot alkalmaztunk.

A hipotézisvizsgálat módszertana:

A hipotézis fogalma: egy meghatározott sokaság valamely paraméterére vagy eloszlására vonatkozó állítást hipotézisnek nevezünk. Hipotézis ellenőrzésekor egy adott matematikai statisztikai módszer, alkalmazásával egy véletlen minta alapján eldönthető, hogy az állítás elfogadható vagy elutasítandó. Azt az állítást, amelynek elfogadásáról a vizsgálat során döntés születik nullhipotézisnek nevezzük. Ez azt jelenti, hogy a valóság és a hipotézis között nulla a differencia. Alternatív hipotézisnek nevezzük a nullhipotézis ellentettjét. Tehát a nullhipotézis elfogadása az alternatív hipotézis elutasításával jár, míg a nullhipotézis elutasítása az alternatív hipotézis elfogadását vonja maga után (Tátrainé, 2006).

Hipotézisvizsgálatkor a vizsgált sokaságra vonatkoztatott meghatározott feltevés ellenőrzése a cél egy adott minta alapján. Hipotézisvizsgálatainkat Z-teszt segítségével végeztük, ahol egy állítás helytállóságát vizsgáltuk a feltüntetett minta alapján 95\%-os valószínüséggel (Hampel, 2018). Hasonló kérdőíves felmérést végeztek 2010-ben (Gál et al., 2010). A mintaelemek egy függvényét, melynek valószínűség-eloszlása ismert, a nullhipotézis helyességének feltételezése mellett, próbafüggvénynek nevezzük. A próbafüggvény értéke elöre megadott valószínüséggel az elfogadási tartományba esik, amennyiben ez nem következik be, akkor a kritikus-, vagy elutasítási tartományba kerül a próbafüggvény értéke.

Összegezve tehát első lépésként a minta adathalmazának segítségével kiszámoljuk a próbafüggvényt. Amennyiben ez beleesik az elfogadási tartományba, akkor a nullhipotézist elfogadjuk és az alternatív hipotézist utasítjuk el, azonban, ha a kapott érték a kritikus tartomány részét képezi, azaz kívül esik az elfogadási tartományon, abban az esetben az alternatív hipotézist fogadjuk el és a nullhipotézis kerül elutasításra. Ezen döntés során követhetünk el hibákat. A következő kettő a leggyakoribb. Első fajú hiba: a nullhipotézis elutasítása annak fennállása esetén. Másodfajú hiba: a nullhipotézis elfogadása abban az esetben, ha az valójában nem áll fenn. Szignifikancia szintnek nevezzük azt a valószínüségi értéket, amellyel a próbafüggvény a kritikus tartományba esik (Tátrainé, 2006).

Hipotéziseink vizsgálatához számos matematikai statisztikai módszer közül választhatunk. Hipotézisvizsgálatra alkalmas módszer a Z-próba is, amely mennyiségi változók esetén használatos. Munkánk során hipotéziseinket $\mathrm{Z}$ próbával vizsgáltuk (Tóthné, 2008). 


\section{1. ábra: Baloldali statisztikai próba szemléltetése}

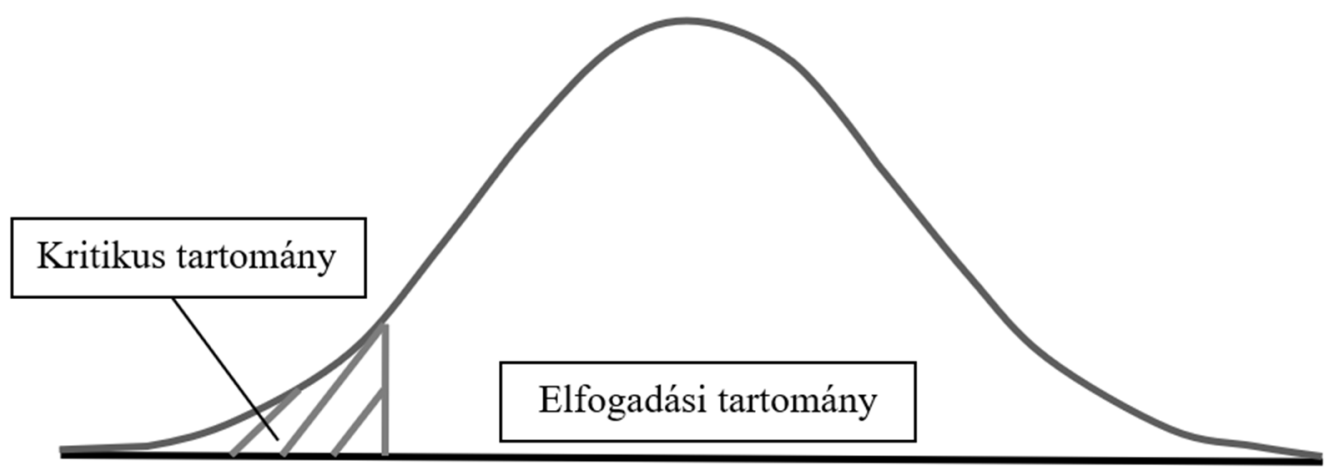

Forrás: a szerző saját szerkesztése

A fent említett próbák közül a vizsgálatok során bal oldali próbákkal dolgoztunk. Baloldali próbának nevezzük, ha a kritikus tartomány a függvény bal oldalán jelenik meg, így a jobboldalon az elfogadási tartomány helyezkedik el (1. ábra). Így a nullhipotézist abban az esetben fogadtuk el, mikor a kiszámított Z-érték nagyobb lett, mint a kritikus érték. A vizsgálatokat az alábbi képlet segítségével végeztük:

$$
Z=\frac{p-P}{\sqrt{\frac{P(1-P)}{n}}}
$$

A fenti képlet segítségével minden hipotézisünket vizsgálni tudtuk. Egyértelmü eredmények születtek, az adott hipotézis elfogadhatóságának tekintetében.

\section{Eredmények és értékelésük}

Az áfacsökkentés jelenleg még nem hozta meg a várt eredményt, azonban elképzelhetö, hogy ez csupán idő kérdése. A halfogyasztás növekedése nem számottevő. Ez elmondható a halhús áráról is.

Nem lehet sokkal olcsóbban hozzájutni a halhoz. Ennek egyik oka lehet, hogy idén ismét felütötte a fejét a halherpesz, melynek következtében ötödével kevesebb hal lett, mint az előző években. Ökonómiai szempontból ez nem hagyható figyelmen kívül, hiszen a kínálat csökkenése az ár növekedését vonja maga után.

A hipotézisek vizsgálata:

1. Hipotézis: Feltételezzük, hogy a kérdőívet kitöltő halfogyasztók nagyobb része csupán ritkán (maximum évi 1-2 alkalommal) fogyaszt halat.

n=286 (a minta nagysága)

A fenti állítással egyetért:99 fő

k=99 (nullhipotézisnek megfelelően válaszolók száma)

Nem ért egyet: 187 fö

$\mathrm{P}=0,5000$ (a feltételezett érték)

Összes válaszadó: 286 fő 
$\mathrm{p}=\mathrm{k} / \mathrm{n}=0,3462$ (a mintából számított érték)

Z-próba: $\mathrm{H}_{0}: \mathrm{p} \geq 0,5 \leftarrow$ Nullhipotézis.

$\mathrm{H}_{\mathrm{A}}: \mathrm{p}<0,5 \quad \leftarrow$ Alternatív hipotézis, a relációjel alapján bal oldali próba. $\downarrow$

(Bal oldali próbánál elfogadjuk a nullhipotézist, ha z-érték > kritikus érték.)

Szignifikancia szint: $\alpha=0,05$ (hibavalószínűség)

Az elfogadási tartomány (kritikus érték): $Z_{0,05}=-1,645$

Alkalmazott képlet:

$$
Z=\frac{k-n P}{\sqrt{n P(1-P)}} \text { vagy } Z=\frac{p-P}{\sqrt{\frac{P(1-P)}{n}}}
$$

\section{A Z-próba értéke: - 5,202}

Statisztikai következtetés: A Z-próba értéke kisebb a kritikus értéknél $\rightarrow$ a nullhipotézist elutasítjuk 5\%-os szignifikancia szinten, illetve 95\%-os valószínűség mellett.

Szakmai következtetés: A megkérdezett halfogyasztók nem csupán ritkán (évente 1-2 alkalommal) fogyasztanak halhúst.

2. Hipotézis: A megkérdezettek legalább 50\%-a szerint jót tesz az egészségnek a rendszeres halfogyasztás.

$\mathrm{n}=407$ (a minta nagysága)

A fenti állítással egyetért:349 fö

k=349 (nullhipotézisnek megfelelően válaszolók száma)

Nem ért egyet: 58 fö

$\mathrm{P}=0,5000$ (a feltételezett érték)

Összes válaszadó: 407 fö

$\mathrm{p}=\mathrm{k} / \mathrm{n}=0,8575$ (a mintából számított érték)

Z-próba: $\mathrm{H}_{0}: \mathrm{p} \geq 0,5 \leftarrow$ Nullhipotézis.

$\mathrm{H}_{\mathrm{A}}: \mathrm{p}<0,5 \quad \leftarrow$ Alternatív hipotézis, a relációjel alapján bal oldali próba. $\downarrow$

(Bal oldali próbánál elfogadjuk a nullhipotézist, ha z-érték > kritikus érték.)

Szignifikancia szint: $\alpha=0,05$ (hibavalószínüség)

Az elfogadási tartomány (kritikus érték): $Z_{0,05}=-1,645$

Alkalmazott képlet:

$$
Z=\frac{k-n P}{\sqrt{n P(1-P)}} \text { vagy } Z=\frac{p-P}{\sqrt{\frac{P(1-P)}{n}}}
$$

\section{A Z-próba értéke: 14,42}

Statisztikai következtetés: A Z-próba értéke nagyobb a kritikus értéknél $\rightarrow$ a nullhipotézist elfogadjuk 5\%-os szignifikancia szinten, illetve 95\%-os valószínűség mellett.

Szakmai következtetés: A válaszadók több mint fele úgy gondolja, hogy jót tesz az egészségnek a rendszeres halfogyasztás. 
3. Hipotézis: A beltartalmi értékek közül a legismertebb az omega-3 zsírsav.

n=239 (a minta nagysága)

A fenti állítással egyetért: 136 fö

k=136 (nullhipotézisnek megfelelően válaszolók száma)

Nem ért egyet: 103 fö

$\mathrm{P}=0,5000$ (a feltételezett érték)

Összes válaszadó: 239 fö

$\mathrm{p}=\mathrm{k} / \mathrm{n}=0,5690$ (a mintából számított érték)

Z-próba: $\mathrm{H}_{0}: \mathrm{p} \geq 0,5 \leftarrow$ Nullhipotézis.

$\mathrm{H}_{\mathrm{A}}: \mathrm{p}<0,5 \quad \leftarrow$ Alternatív hipotézis, a relációjel alapján bal oldali próba. $\downarrow$

(Bal oldali próbánál elfogadjuk a nullhipotézist, ha z-érték > kritikus érték.)

Szignifikancia szint: $\alpha=0,05$ (hibavalószínűség)

Az elfogadási tartomány (kritikus érték): $Z_{0,05}=-1,645$

Alkalmazott képlet:

$$
Z=\frac{k-n P}{\sqrt{n P(1-P)}} \text { vagy } Z=\frac{p-P}{\sqrt{\frac{P(1-P)}{n}}}
$$

\section{A Z-próba értéke: 2,1334}

Statisztikai következtetés: A Z-próba értéke nagyobb a kritikus értéknél $\rightarrow$ a nullhipotézist elfogadjuk 5\%-os szignifikancia szinten, illetve 95\%-os valószínüség mellett.

Szakmai következtetés: A felsorakoztatott beltartalmi értékek közül az omega-3 zsírsav a legismertebb.

4. Hipotézis: A válaszadók többsége szerint (>50\%) növelni kellene a halhúsfogyasztást.

n=407 (a minta nagysága)

A fenti állítással egyetért:280 fö

k=280 (nullhipotézisnek megfelelően válaszolók száma)

Nem ért egyet: 127 fö

$\mathrm{P}=0,5000$ (a feltételezett érték)

Összes válaszadó: 407 fö

$\mathrm{p}=\mathrm{k} / \mathrm{n}=0,688$ (a mintából számított érték)

Z-próba: $\mathrm{H}_{0}: \mathrm{p} \geq 0,5 \leftarrow$ Nullhipotézis.

$\mathrm{H}_{\mathrm{A}}: \mathrm{p}<0,5 \quad \leftarrow$ Alternatív hipotézis, a relációjel alapján bal oldali próba. $\downarrow$

(Bal oldali próbánál elfogadjuk a nullhipotézist, ha z-érték > kritikus érték.)

Szignifikancia szint: $\alpha=0,05$ (hibavalószínüség)

Az elfogadási tartomány (kritikus érték): $Z_{0,05}=-1,645$

Alkalmazott képlet: 


$$
Z=\frac{k-n P}{\sqrt{n P(1-P)}} \operatorname{vagy} Z=\frac{p-P}{\sqrt{\frac{P(1-P)}{n}}}
$$

\section{A Z-próba értéke: $\mathbf{7 , 5 8 5 5}$}

Statisztikai következtetés: A Z-próba értéke nagyobb a kritikus értéknél $\rightarrow$ a nullhipotézist elfogadjuk 5\%-os szignifikancia szinten, illetve 95\%-os valószínűség mellett.

Szakmai következtetés: A vizsgált sokaság szereplöinek több mint fele egyetért abban, hogy növelni kellene a halhús fogyasztás mértékét hazánkban.

4. Hipotézis: A kitöltők (családjában) növekedett a halfogyasztás mértéke az áfacsökkentés hatására.

$\mathrm{n}=407$ (a minta nagysága)

A fenti állítással egyetért:46 fö

k=46 (nullhipotézisnek megfelelően válaszolók száma)

Nem ért egyet: 361 fö

$\mathrm{P}=0,5000$ (a feltételezett érték)

Összes válaszadó: 407 fö

$\mathrm{p}=\mathrm{k} / \mathrm{n}=0,1130$ (a mintából számított érték)

Z-próba: $\mathrm{H}_{0}: \mathrm{p} \geq 0,5 \leftarrow$ Nullhipotézis.

$\mathrm{H}_{\mathrm{A}}: \mathrm{p}<0,5 \quad \leftarrow$ Alternatív hipotézis, a relációjel alapján bal oldali próba. $\downarrow$

(Bal oldali próbánál elfogadjuk a nullhipotézist, ha z-érték > kritikus érték.)

Szignifikancia szint: $\alpha=0,05$ (hibavalószínüség)

Az elfogadási tartomány (kritikus érték): $\mathrm{Z}_{0,05}=-1,645$

Alkalmazott képlet:

$$
Z=\frac{k-n P}{\sqrt{n P(1-P)}} \text { vagy } Z=\frac{p-P}{\sqrt{\frac{P(1-P)}{n}}}
$$

\section{A Z-próba értéke: - 15,6149}

Statisztikai következtetés: A Z-próba értéke kisebb a kritikus értéknél $\rightarrow$ a nullhipotézist elutasítjuk 5\%-os szignifikancia szinten, illetve 95\%-os valószínűség mellett.

Szakmai következtetés: A kitöltők családjában nem növekedett a halhús fogyasztás mértéke az áfacsökkentés hatására.

\section{Következtetések, összegzés, záró megjegyzések, záró gondolatok}

Saját elhatározásból, vagy környezetünk befolyásoló hatása miatt törekszünk az egészséges életmód kialakítására. Ebben nagy szerepet játszik a globalizáció is, hiszen a kialakult food-trendek hatást gyakorolnak egyéni étkezéseinkre. Témaválasztásunk alkalmával igyekeztünk érdeklődési körünknek megfelelő mellett dönteni. Rendkívül fontosnak tartjuk az egészséges életmódra való törekvést, ezért döntöttünk úgy, hogy ezt a témát választjuk. 
A rendszeres halfogyasztás számos módon támogatja az emberi szervezet megfelelő müködését. Különböző vitaminokkal és ásványi anyagokkal segíti immunrendszerünket és a betegségekkel szembeni ellenálló képességünket. Tengeri halak fogyasztásával omega-3 többszörösen telítetlen zsírsavat biztosíthatunk szervezetünk számára, ami rendkívüli jelentőséggel bír, hiszen ezt külső forrásból szükséges biztosítani, mert a szervezet nem képes önmagának előállítani.

Magyarország statisztikai adatai elszomorítóak az egy főre jutó éves halfogyasztás tekintetében. 2013-ban kicsit több mint 3 kg körül alakult. 2017-re ez 5,7 kg-ra emelkedett. A növekvő tendencia bíztató, azonban még így is jelentős különbség figyelhető meg más országokhoz képest, ahol ez az érték akár 30-40 kg is lehet.

2018-ban 27\%-ról 5\%-ra csökkentették a fogyasztási célú halak áfáját a halfogyasztás mértékének növelése céljából. Munkák során ennek hatását is vizsgáltuk, azonban ebben a tekintetben nem volt megfigyelhető jelentős változás. Ennek számos oka lehet, például egy betegség, amely az emberre nem veszélyes, azonban a halmennyiség az idei évben ötödével kevesebb lett. Ez a betegség a halherpesz. Jelentős mértékben csökkent miatta a kínálat, ezért az ár növekedett, így az áfacsökkentés hatása nem érzékelhető. Hasonló eredményt kaptunk a polcfelmérés alkalmával is. Valamivel olcsóbban lehet élő pontyot vásárolni a Szegedfish Kft-nél, mint a tavalyi évben, azonban a különbség nem számottevő, szinte megegyezik a 2016-os adatokkal.

Összesen öt hipotézist fogalmaztunk meg. Ezeket statisztikai módszerrel (Zpróbával) vizsgáltuk. A kapott eredmények alapján két hipotézist utasítottunk el és három hipotézis került elfogadásra. A vizsgálatok során kiderült, hogy az általunk megkérdezettek nagy része tisztában van a halfogyasztás szervezetre gyakorolt jótékony hatásaival, és a legtöbben rendszeresen fogyasztanak is halat. Azonban ez nem az áfacsökkentésnek köszönhetö.

A témához kapcsolódó javaslataink:

- A halfogyasztásban megfigyelhetö szezonalitás miatt javasoljuk egy felmérés elvégzését az ünnepi időszakban és a kapott adatok összehasonlítását a korábbi évek hasonló időszakaival,

- az egészséges életmód és ezzel a halfogyasztás népszerüsítését az oktatási intézményekben, hogy a fiatalok számára megszokott legyen ez az életmód,

- a halfogyasztás szervezetre gyakorolt jótékony hatásainak tudatosítását a fogyasztókban,

- a friss és egészséges halhús és abból készült termékek több helyen való árusítását,

- halat felhasználó receptek, videók készítését, terjesztését a média különböző csatornáin keresztül. 


\section{Köszönetnyilvánítás}

AZ EMBERI ERÖFORRÁSOK MiNISZTÉRIUMA UNKP-18-1 KÓDSZÁMÚ ÚJ NEMZETI KIVÁLÓSÁG PROGRAMJÁNAK TÁMOGATÁSÁVAL KÉSZÜLT
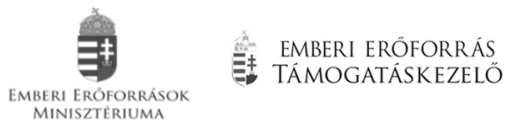

Nemzeti

Tehetség Program

\section{Irodalomjegyzék}

Antal M., Rodler I. (2005): Táplálkozással összefüggő krónikus megbetegedések. In: Rodler I. (szerk.): Élelmezés-és táplálkozásegészségtan. Medicina Könyvkiadó Zrt., Budapest, 141-185.

Fürediné Kovács A. (2008): A fogyasztók egészségügyi kockázatészlelése és kockázatredukciós magatartásának vizsgálata. Doktori értekezés. Szent István Egyetem, Gazdaság és Társadalomtudományi kar, Marketing intézet, Gödöllő.

Gál J., Németh M., Vincze-Lendvai E. (2010): Bébiétel vásárlási és fogyasztási szokások Sándorfalván. In: Csépe A. (szerk.): „Új marketing világrend”, Budapesti Kommunikációs és Üzleti Főiskola, 295-299.

Hampel Gy. (2018): Information and Information Systems as Keys to Success. QUAESTUS Multidisciplinary Research Journal, 13, 71-82.

Herman O. (1887): A magyar halászat könyve. Természettudományi Könyvkiadó-Vállalat, Budapest. Horváth Gy. (2004): A kérdöíves módszer. Müszaki Könyvkiadó, Budapest.

HVG.Hu (2018): Hiába volt áfacsökkentés, nem lett sokkal olcsóbb a hal. <https://hvg.hu/gazdasag/20180216_Hiaba_volt_afacsokkentes_nem_lett_sokkal_olcsobb_a_h al> (2018.09.25.)

Kiss M., Szakály Z., Soós M., Kontor E. (2016): Az egészségtudatosság megjelenése a magyar lakosság táplálkozási szokásaiban korcsoportonként, In: Bíró L., Gelencsér É., Lugasi A., Rurik I. (szerk.): A 60 éves Magyar Táplálkozástudományi Társaság XLI. vándorgyülése: Program és az elöadások kivonatai, Esztergom, Magyarország, 2016.10.06-2016.10.08. Budapest: Magyar Táplálkozástudományi Társaság, p. 38.

Kontor E., Szakály Z., Soós M., Kiss M. (2016): Egészségtudatos magatartás a 14-25 év közötti fiatalok körében, In: Fehér A., Kiss V. Á., Soós M., Szakály Z. (szerk.): Hitelesség és Értékorientáció a Marketingben. Debreceni Egyetem Gazdaságtudományi Kar, Debrecen, 640649.

Kotler P. (1999): Kotler on Marketing, How to create, win and dominate Markets. The Free Press, New York 1999.

KSH (2016): Élelmiszerek egy före jutó hazai fogyasztása (1970-) <http://www.ksh.hu/docs/hun/ xtabla/elelmfogy/tablelm15.html> (2018.10.16.)

Lantos Z. (2010): Az egészséges és az egészségesnek gondolt táplálkozás trendjei. Élelmiszer, táplálkozás és marketing, 7 (1): 37-40.

Lehota J. (2001): Marketingkutatás az agrárgazdaságban. Mezőgazda Kiadó, Budapest.

Majoros P. (1997): Kutatásmódszertan, avagy hogyan írjunk könnyen, gyorsan jó diplomamunkát. Nemzeti Tankönyvkiadó, Budapest.

MDOSZ (2007): Táplálkozás és Tudomány hírlevél, 8 (6) <https://mdosz.hu/hun/wpcontent/uploads/2016/03/2007_06_tt.pdf> (2018.10.16.)

MTI (2018): Csökken a hal áfája, most olcsóbban lehet venni. <https://hvg.hu/gazdasag/ 20180108_Csokkent_a_hal_afaja_most_olcsobban_lehet_venni> (2018.08.27.)

Pintér K. (1989): Magyarország halai. Akadémiai Kiadó, Budapest.

Rácz G. (2013): Az értékek változásának és a fenntartható fejlödés trendjének hatása a hazai élelmiszerfogyasztásra. Doktori értekezés. Szent István Egyetem, Gazdálkodás és Szervezéstudományok Doktori Iskola.

Rodler I. (2005): Új Tápanyagtáblázat. Medicina Kiadó, Budapest. 
Szakály Z. (2009): Egészségmagatartás és funkcionális élelmiszerek: hogyan vélekednek a hazai fogyasztók? Élelmiszer, táplálkozás, marketing, 7 (1): 9-19.

Szakály Z. (2017): Élelmiszer-marketing. Akadémiai Kiadó, Budapest.

Szegedfish Kft. (2018): Szegedfish Kft. honlapja. <http://szegedfish.hu/> (2018.10.16.)

Takács Z. (2006): Magyar néprajzi lexikon. Hallgatói Információs Központ, Budapest.

Tasnádi-Kovács A., Szilágyi M. (szerk.) (2001): Magyar Néprajz, II. kötet, Halgazdálkodás. Akadémiai Kiadó, Budapest.

Tátrainé K. E. K. (2006): Statisztika. Elektronikus jegyzet. ‘http://jegyzet.sze.hu/letolt.php? dwn=1statisztika> (2018.10.16.)

Tóthné Lőkös K. (2008): Statisztika II. Századvég Kiadó, Budapest.

Töröcsik, M. (2007): Food-trendek és vásárlói trendcsoportok. Acta Oeconomica Kaposvariensis, 1 (1-2): 51-65.

Túry, K. (2008): Étel, evés és nemzeti identitás. Pro Die Kiadó Kft, Budapest. 